\title{
The favoured child?
}

\author{
David Jones, Donna Dickenson and John Devereux
}

Park Hospital, Oxford, The Open University, Milton Keynes and Griffiths University, Brisbane, Australia respectively

\section{Authors' abstract}

This case conference concerns a child who has been in care following a diagnosis of emotional abuse and a serious incident of physical abuse. She wants to return home again, and her parents, who had previously scapegoated her, now blame the family's previous ills on her sister instead. The Children Act 1989 gives considerable weight to the child's wishes, but what if the child returns home and is re-abused? In this case conference a child psychiatrist, a philosopher and a lawyer discuss the issues of clinicians' responsibilities, moral luck, and child care law.

\section{Case}

Jane is an eleven-year-old girl who has been living in a residential children's home in the Midlands since she was eight. Now she wants to go home, and her parents want her to return. She has been visiting them regularly during the past year, and on the face of it the decision which the court now has to make appears simple. But in fact the decision surrounding Jane's predicament is very difficult.

Before being received into care, Jane was living at home with her older half-sister, Eileen, her mother's child by another union, and a younger full sibling. The half-sister is four years older than Jane, and the full brother five years younger.

When Jane was six, there was an episode of unexplained bruising. She was placed on the child abuse register, but after a period in foster care she was returned to her parents. By the time she was seven, Jane's behaviour was extremely disturbed. She was disobedient, oppositional and prone to lying and swearing. Most disturbingly of all, she was setting fires in her home.

At the age of seven years and four months, Jane was referred to and treated by a child psychiatric team. She appeared to respond to this approach, but parallel work with her parents made no progress. Although the clinic staff tried to be flexible, the parents refused all the offered appointment times,

\section{Key words}

Consent (child's); child abuse. and blamed social services and the psychiatric team $\stackrel{\circ}{\circ}$ for the family's problems.

The psychiatric team made a primary diagnosis of $\vec{\infty}$ emotional abuse. They considered that the family scapegoated Jane, constantly criticising and belittling her. Case work with the family was attempted by the social services department, but proved difficult and frustrating for the staff.

When Jane was just eight years old, she was $\ddot{\&}$ severely physically attacked by her father in an $\$$ outburst of rage. She was admitted, covered in bruises, to the local paediatric ward and then to a residential children's home, where she has remained. In the past three and a half years there have been several attempts to rehabilitate Jane with her natural $\stackrel{\mathbb{\triangle}}{\triangle}$ parents, all of which have failed - because of lack of $\vec{\overrightarrow{ }}$ co-operation from the parents, staff considered. The family continued to scapegoat Jane and to favour her older half-sister, Eileen, although, according to her school report, Eileen had numerous behavioural difficulties.

When Jane was ten, Eileen unexpectedly requested to be received into care herself, and was admitted to the same residential children's home as Jane. After a few weeks there, she alleged that she had been sexually abused by her stepfather. This was 윽 a turning point for Jane: her parents reversed their $>$ affections. Now they insisted that Eileen had been the bad seed all along, tricking them into believing $\tilde{N}$ that Jane was the cause of all the tensions and misdeeds in the home.

Within months Jane had responded accordingly to $\mathrm{N}$ her changed fortunes in the family, beginning to express a strong wish to return home. Since the age of ten and a half she had made regular visits, $\mathbb{\complement}$ spending a day of each weekend with her natural + parents. But because the clinic staff and social $\frac{0}{0}$ services did not see Jane's future as being with her $\frac{\text { Pे }}{\mathbb{D}}$ family of origin, she was also encouraged to develop $\stackrel{\odot}{\stackrel{\odot}{\odot}}$ a relationship with a family near the children's $\mathscr{\mathbb { }}$ home, whom she visited on one or two nights of the week and with whom she had formed a close, $\delta$ affectionate relationship.

Jane and Eileen have always had an argumentative and hostile relationship with each other: Jane imitates her parents' criticisms of Eileen's behaviour. 
Six months ago Eileen was placed with a foster family, as there seemed no prospect of her returning home. Now the children's home in which the sisters had lived is being closed down. As the court makes its decision, only four children remain there, adding urgency to the case and the weight of expediency to Jane's expressed wishes.

\section{Commentary: Child psychiatrist}

I saw Jane in order to assess her mental state and her perspective on her current predicament. She was a bright, rather agitated youngster, with little confidence in herself but some pride in her sporting and educational achievements. Although she appeared emotionally immature in some of her reactions and responses, she was worldly-wise about dealing with members of the caring professions. She knew how to give me just enough material to make me feel that I was doing a good job, while revealing little personal information. Jane was vigilant and wary, denying any difficulties in her family and refusing to talk about her past history of physical abuse.

Jane told me on more than one occasion that she wanted to go home and had no doubts that all would be well. But while she was telling me this, she became much more agitated, literally jumping around the room and all over the sofa, unable to sit still for a moment or to look me in the eye. Nor could she tell me anything more of her feelings about returning home, other than repeating that all would be well.

My clinical conclusion was that Jane expressed significant anxiety and certainly ambivalence about returning home, especially non-verbally - despite her overtly expressed wishes. There seemed to be several factors contributing to this ambivalence (1). Her memories of abuse and violence in the home were unresolved and apparently denied. I considered that her relationship with her parents was probably abnormal, showing evidence of an anxious attachment pattern. She needed close affectionate relationships and was relatively indiscriminate in her interaction with adult figures. This left her vulnerable in terms of personal relationships for the future, although she did enjoy a good rapport with the befriending foster family, who would, fortunately, still be able to see her when the residential home closed. Her own family's style, I thought, was typified by divide and rule, and Jane was now re-enacting this pattern with Eileen.

I saw Jane's parents separately. They reeled off a catalogue of complaints about Eileen, but saw no difficulties in Jane's return home. Jane's father was more forthcoming than I expected, relating some of his own experiences of abuse and harsh parenting as a child and his reception into care as a teenager. $\mathrm{He}$ had made connections in his mind between the violence he had experienced and witnessed as a child, and his own difficulties as a parent. Both parents assured me that they were prepared to participate in family therapy focused on helping them to acknowledge and take responsibility for the prior violence towards Jane. They agreed that this work would take time, and that the best way forward would be a graded trial of whether rehabilitation could be possible. But I remembered that the family had failed to follow through with the clinical work that had been recommended before.

What should I do? Jane is determined to sabotage any alternative placement which I can arrange, and I had been presented with a fait accompli in another sense, too: she had already been visiting her parents for a year before I saw her. Did that augur well? Perhaps the family would be willing to engage in the necessary therapy this time? A graded increase in contact with her parents might also make Jane more realistic about them. Her wishes at the time of assessment seemed guided by a fantasy of how perfect the family might be, 'if only'.

But suppose Jane had already become cemented into the family pattern of secrecy? Were her expressed wishes to return only a measure of her anxiety caused by the lack of a satisfactory, close-attachment relationship with her parents? Even worse, might she be aligned with, and determined to re-enact, a pattern of repeat victimisation? Worse still, suppose sexual abuse was the fate of the favoured child within the family? Eileen's allegations were considered unsubstantiated, but how could I be sure?

My recommendation to the court was a trial of rehabilitation, with a graded increase in access contact. Alongside this I recommended that directions be attached for family therapy work (which I had provisionally arranged through a colleague who worked in that locality). At the same time, I felt that there should be continuing support for Jane outside the immediate family context, through strengthening the contact with the befriending foster family and making specific arrangements for further befriending by one of the key workers in the residential home after its closure. A review of progress with a requirement to report to the court was arranged through limiting the length of the access contact order, so that a review would be required before the court. The court accepted these recommendations and set up the review date.

Under the Children Act 1989, which gives express weight to the child's wishes in the 'welfare check-list' that the court must consider, I felt that I had achieved the best I could. But once Jane is locked into her family's structure of secrecy she could be abused again, and yet unable to tell anyone. The thought of her being re-abused physically, or even sexually abused, haunts me.

\section{Commentary: Philosopher}

How much is a clinician responsible for? If Jane is re-abused physically, or sexually abused, will this 
child psychiatrist feel that it is his fault? In the last sentence of his report, he says: 'The thought of her being re-abused physically, or even sexually abused, haunts me'. Yet the requirements of the law - with the particular emphasis placed on the child's voice by the Children Act - combine with the practicalities (Jane will subvert any other placement) to leave him little choice.

This is a case about what philosophers term 'moral luck' (2). The nub of the moral luck paradox concerns responsibility. On the one hand we regard actions as right or wrong partly according to what happens as the result of the moral agent's decision. Thus we make responsibility hinge to some extent on things outside the moral agent's control. In some recent UK cases social workers were dismissed for failing to prevent children's deaths through abuse, although they were not responsible for the killings: the abusers were. At most they were negatively responsible: for 'sins' of omission rather than commission. But it is difficult to see what the psychiatrist has omitted to do: he has set in place all the precautionary mechanisms which the law allows - yet Jane could still be abused when she returns home. He has lessened the chances of that, but not to zero.

However, we also think that people should not be held responsible for matters beyond their control. This is the second arm of the moral luck paradox. The doctor has very little control over whether Jane's father re-abuses her, given the family's unwillingness to co-operate with therapy. The law absolves the psychiatrist further, even requiring him to go against his own clinical judgement. But he feels responsible and perhaps we not-so-secretly want the best doctors to be that way, despite our ostensible conviction that people should not be held responsible for matters beyond their control.

If so, then we must face the likelihood of burnout and disillusion in health care workers who live daily with the paradox of moral luck. Clinicians who allocate scarce medical resources such as kidneys, for example, may also blame themselves if the kidney is 'wasted' on a patient whose good prognosis was a mirage. Nurses who must divide their time among several gravely ill patients may blame themselves if they choose to spend extra time with the one who appears neediest, but another worsens or dies (3).

In an era of staff shortages and cutbacks, we have testimony from nurses that their best efforts are insufficient through no fault of their own. By attempting to ward off future (unmerited) guilt by alerting his managers and the health authorities to the three or four unsupervised deaths which might occur in a single night on the geriatric ward where he was sometimes the only nurse, Graham Pink made himself a scapegoat and was dismissed. Acting too responsibly can endanger your job.

How then can professionals who feel such a supererogatory (above-and-beyond-the-call-of-duty) sense of responsibility learn to live with themselves? How can they narrow down their sense of what they need to get right?

Many philosophers distinguish between regret, 을 which applies to external situations which have gone wrong, and remorse, felt about one's own voluntary $\frac{\sigma}{\partial}$ actions. The first is a project failure, the second $\stackrel{\mathbb{}}{\varrho}$ personal. What would prove Jane's child psychiatrist $\nRightarrow$ wrong, then, would not be if his project failed, but $\vec{\circ}$ that he failed, to paraphrase Bernard Williams's discussion of 'moral luck' (2). If Jane is hurt again, $\vec{\omega}$ he will certainly experience regret: but constrained $\stackrel{\circ}{S}$ by the law as he was, his action in letting her go home was not fully voluntary, and he should not î experience remorse.

But is regret the right emotion? The problem is that we experience regret about such trivial things. If $\infty$ the used car I buy turns out to be a lemon, even 응 though I have diligently perused What Car?, I regret $\rightarrow$ my choice. If the film I choose turns out to be a $\subseteq$ disappointment, I regret the wasted evening. If I buy shoes at full price and find that they are marked $\vec{\bullet}$ down to half price in a sale the next day, I regret my $\&$ haste. All of these are minor annoyances: Jane's abuse would be a tragedy.

Do we want the clinician to divorce himself from Jane's well-being to the extent of merely regarding it as his 'project', of merely experiencing regret if she is abused? Or do we want him to feel that he has failed as a moral agent, that he is personally blameworthy, $\overline{\overrightarrow{0}}$ if she is hurt again? I cannot think that we want him 3 to blame himself as deeply as if he had not set up the necessary failsafe mechanisms - even if they do fail after all.

How much good it will be to the doctor I don't know: but I think he needs to feel responsible for $\frac{5}{3}$ taking Jane seriously, responding to her desires as if they were autonomous - whether or not he suspects $O$ that she is actually being used as her parents' mouthpiece. He also needs to feel responsible for $\stackrel{\circ}{工}$ following the procedures which minimise risk. All $\frac{D}{2}$ this he has done.

I do not think that he should feel himself to be o responsible for the outcome. Within the narrower $N$ range of getting the procedures rather than the outcome right, clinicians' responsibility is complete: $\omega$ they must not shirk getting a truly informed consent, for example, but they are not responsible if the procedure turns out badly - unless, of course, they have acted negligently. It is getting the consent, or + treating the child's wishes seriously, which transfers ${ }^{\circ}$ the responsibility for the outcome from clinician to $\vec{D}$ patient. At what age a patient can begin to bear her $\frac{?}{\mathbb{D}}$ own share of responsibility is a question for the law $\cong$ to resolve more clearly (4).

\section{Commentary: Lawyer}

The determination of Jane's future placement will, in law, turn on the question of what is in Jane's best 
interests. In other words, which solution will best promote her welfare?

Section 1 of the Children Act 1989 outlines a check-list to assist a court in determining what a child's welfare demands. The first, though by no means paramount, consideration, is the ascertainable wishes of the child.

The law is often binary in nature. A contract is void, or it is valid. A person is guilty as charged, or not guilty. Jane states that she wants to be reunited with her family: on the face of it, to a lawyer the matter seems clear.

But in being so categorical, does the law adequately reflect psychological reality? J J Strain (5) has pointed out that two types of thinking may be isolated. On the one hand, manifest thinking is in the realm of awareness. It represents explicit communication to others; it is conscious, and may be recalled. Latent content, by contrast, is grounded in the unconscious. It is accessible by introspection or psychotherapy, and is often the material of which dreams and slips of the tongue are made.

While Jane's manifest wish is to be reunited with her parents, her obvious discomfort, her agitation in talking about her family, and her inability to maintain gaze fixation all suggest that her latent thinking is predisposed not to return home.

In addition it should be noted that, by virtue of section 1(3)(c) of the Children Act, in determining the child's welfare the court may consider the likely effect on the child of any change in her circumstances (3). The court may need to know whether, in the psychiatrist's opinion, returning Jane to her parents' home would cause her emotional distress.

Jane's case calls to our attention certain legal changes under the Children Act. The child's voice is a key principle, but it operates within the general framework of two tenets which underpin the Act: first, that a child is best served by staying within his or her family of origin, without recourse to legal proceedings; second, that when changes have to be made, delay is bad for the child (section 1[2]). But questions may legitimately be raised about how important it is to avoid delay, when we can only know if a programme of care is going to work by giving it time to work (6).

A further difficulty in the Act is that it allows certain orders to be varied, but makes no provision for review of child care orders. A way to circumvent this problem is to ask the court to make a supervision order with attached directions. The court may substitute such an order for a care order during the life of the care order (section 39[4]). A supervision order may be varied (section 39[2]). Another approach might be the use of time-limited residence and contact orders, which also permit review by the court.

The Children Act has marked a step forward in recognising that children have rights and should have their views respected in appropriate circumstances. In Jane's case, where her verbally expressed wishes conflict with her non-verbal expressions, it seems that courts will have to have recourse to other items in the welfare check-list to determine Jane's future.

Jane's case raises squarely the question how we can assess what is in the child's best interests. The Act declares unequivocally that the child's welfare is paramount, but what solution will promote her welfare? The Children Act provides a welfare checklist to guide the court in its determination, headed by the child's wishes, to the extent that they can be ascertained. But just what are Jane's wishes?

David fones, $M b C h B, F R C P s y c h, D C H, D(O b s)$ RCOG, BA, DPhil, is a Consultant Child Psychiatrist, Donna Dickenson, $B A, M S c, P h D$, is a Lecturer in Health and Social Welfare at the Open University, and fohn Devereux, BA, LLB, DPhil, is a Senior Lecturer in Law at Griffiths University, Brisbane, Australia.

\section{References}

(1) Jones D P H. Working with the Children Act: tasks and responsibilities of the child and adolescent psychiatrist. In: Lindsey C, ed. Proceedings of the Children Act course. London: Royal College of Psychiatrists, 1991: 23-41.

(2) Williams B. Moral luck. Cambridge: Cambridge University Press, 1981; Nagel T. Moral luck. In: Nagel T, ed. Mortal questions. Cambridge: Cambridge University Press, 1979; Dickenson D. Moral luck in medical ethics and practical politics. Aldershot: Gower, Avebury Series in Philosophy, 1991.

(3) Dickenson D. Nurse time as a scarce health care resource. In: Hunt G, ed. Ethical issues in nursing. London: Routledge, 1994.

(4) Devereux J, Jones D P H, Dickenson D L. Can children withhold consent to treatment? British medical journal 1993; 306: 1459-1461.

(5) Strain J J. Manifest versus latent content. Paper delivered at the Oxford-Mt Sinai conference on bioethics, 1992, Apr 8, Mt Sinai Hospital, New York City.

(6) Re C (1992). Family court reporter vol 2: 341. 